ISSN 1112-9867

\title{
ANTIBACTERIAL AND IN VITRO ANTIOXIDANT ACTIVITIES OF SOME
}

4-AMINO-1,2,4-TRIAZOLE-5(4H)-THIONE DERIVATIVES

\author{
P. S. Manjula ${ }^{1}$, B. K. Sarojini ${ }^{1,2}{ }^{*}$, C. G. Darshan Raj ${ }^{1}$ \\ ${ }^{1}$ Department of Chemistry, P.A College of Engineering, Nadupadavu, Mangalore-574153. \\ ${ }^{2}$ Department of Industrial Chemistry, Mangalore University, Mangalagangothri, \\ Mangalore-574199 \\ Received: 20 May 2015 / Accepted: 28 August 2015 / Published online: 1 September 2015
}

\section{ABSTRACT}

This work represents the synthesis and characterization some new versatile intermediates namely 4-amino-1,2,4-triazole-5(4H)-thione derivatives in a one-step fusion method. The method works to be superior compared to the existing method by Reed and Handel which consists of four steps. The antibacterial activity of compounds is tested against Escherichia coli, Bacillus subtilis, Pseudomonas aeruginosa, Staphilococcus aureus. The compounds exhibited species specific activity. Among the tested compounds, 1a and $\mathbf{1 b}$ exhibited good activity at moderately low concentration $(31.25 \mu \mathrm{g} / \mathrm{mL})$ against tested strains of bacteria. DPPH (1,1-diphenyl-2-picryl-hydrazyl), FRAP (ferric reducing antioxidant power) and Lipid peroxidation assays are performed to determine the in vitro antioxidant activities. The compound 1e exhibited good antioxidant activity among the tested compounds.

Keywords: 1,2,4-triazole; Antibacterial; In vitro; Antioxidant; DPPH assay; FRAP assay; Lipid Peroxidation assay.

Author Correspondence, e-mail: darshanraj22@gmail.com

doi: http://dx.doi.org/10.4314/jfas.v7i3.7

\section{INTRODUCTION}

Triazole is a five membered ring system with three nitrogen hetero-atoms, which defines an 
interesting class of compounds. It exists in two tautomeric forms, the 1,2,3-triazole and the 1,2,4-triazole . $1 H$ and $4 H$-1,2,4-Triazoles are considered to be pharmacologically important nucleus. The literature shows that 1,2,4-triazole possesses a wide range of biological activities. The considerable biological importance of triazoles has stimulated a lot of interest in its derivatives. 1,2,4-Triazoles have a wide range of therapeutic properties like antibacterial, antifungal, antimycobacterial and antiviral[1].

It has been reported that structural properties of triazoles, like moderate dipole character, hydrogen bonding capability, rigidity and stability under in vivo conditions are the main reasons for their superior pharmacological activities [2].There is an increasing demand for the preparation of new broad spectrum antibacterial compounds due to the developing resistance towards usual antibiotics. Therefore, we have synthesized some 4-amino - 1,2,4-triazole-5 (4H) derivatives possessing antimicrobial and antioxidant activities [3].

Hence in the present work we account, synthesis of some new 4-amino-1,2,4-triazole-5(4H)-thione derivatives, their structural determination by spectral analysis, in vitro antioxidant and antimicrobial analysis.

\section{RESULTS AND DISCUSSION}

The compounds 1a-1e were synthesized as per the scheme (I) and purified by recrystallization.The purity was determined by TLC. Formation of the compounds was confirmed through analytical studies. This method is found to be a superior green method compared to the classical method described by Reid and Handel [4]. The classical method involves the conversion of the starting material acid to ester which in turn converted into acid hydrazide. Both steps involve five hours of refluxing respectively. The acid hydrazide should then be converted into corresponding potassium salt dithiocarbazinate in dry ether medium. Cyclization of this intermediate leads to 5-substituted 4-amino-3-mercapto 1,2,4-triazoles. But the method reported here involves single step fusion reaction with good yield and purity.

\subsection{Antibacterial assay}


Antibacterial screening of the compounds was performed using four different bacterial strains both gram positive and gram negative. All the compounds exhibited activity against tested strains of bacteria. The compound 1a exhibited better activity against Escherichia coli and Staphilococcus aureus strains at MIC 31.25 and $62.5 \mu \mathrm{g} / \mathrm{mL}$ respectively. This might be due the $-\mathrm{Cl}$ group at para position of aromatic nucleus attached to 1,2,4-triazole. The compound $1 \mathrm{~b}$ exhibited better activity against Bacillus Subtilis and Pseudomonas aeruginosa at MIC 31.25 and $62.5 \mu \mathrm{g} / \mathrm{mL}$ respectively. The reason for this was assumed to be the presence of - $\mathrm{Cl}$ group at ortho position of aromatic nucleus. This observation is further supported by the literature studies [5-7].The compound 1c exhibited better activity against Pseudomonas aeruginosa at MIC $62.5 \mu \mathrm{g} / \mathrm{mL}$. The cause for this observation might be the $-\mathrm{OCH}_{3}$ group at meta position of aromatic nucleus adjacent to 1,2,4-triazole. The compounds 1d and 1e exhibited poor activity against all the strains. The reason for this might be the $-\mathrm{CH}_{3}$ and $-\mathrm{OH}$ groups at ortho and para positions respectively on the aromatic nucleus attached to 1,2,4-triazole moiety. The MICs for various strains of bacteria were determined and are depicted in Table 1.

Table 1. Antibacterial activity of synthesised compounds

\begin{tabular}{|c|c|c|c|c|c|c|c|c|}
\hline \multirow{2}{*}{$\begin{array}{l}\text { Micro } \\
\text { Organisms }\end{array}$} & \multirow[t]{2}{*}{ Compds. } & \multicolumn{6}{|c|}{ Concentration in $\mu \mathrm{g} / \mathrm{mL}$} & \multirow{2}{*}{$\begin{array}{c}\text { MIC } \\
(\mu \mathrm{g} / \mathrm{mL})\end{array}$} \\
\hline & & 500 & 250 & 125 & 62.5 & 31.25 & 15.62 & \\
\hline E.coli & 1a & - & - & - & - & - & + & 31.25 \\
\hline \multirow[t]{4}{*}{ ATCC 25922} & $1 \mathrm{~b}$ & - & - & - & - & + & + & 62.5 \\
\hline & $1 \mathrm{c}$ & - & - & - & + & + & + & 125 \\
\hline & $1 d$ & - & - & - & + & + & + & 125 \\
\hline & $1 \mathrm{e}$ & - & - & - & + & + & + & 125 \\
\hline Bacillus & $1 \mathrm{a}$ & - & - & - & - & + & + & 62.5 \\
\hline Subtilis & $1 b$ & - & - & - & - & - & + & 31.25 \\
\hline \multirow[t]{3}{*}{ ATCC 6633} & $1 \mathrm{c}$ & - & - & + & + & + & + & 250 \\
\hline & $1 d$ & - & - & - & + & + & + & 125 \\
\hline & $1 \mathrm{e}$ & - & - & + & + & + & + & 250 \\
\hline Pseudomonas & $1 \mathrm{a}$ & - & - & + & - & + & + & 125 \\
\hline aeruginosa & $1 b$ & - & - & - & - & - & + & 62.5 \\
\hline \multirow[t]{3}{*}{ (re cultured) } & $1 \mathrm{c}$ & - & - & - & - & - & - & 62.5 \\
\hline & $1 d$ & - & + & + & + & + & + & 250 \\
\hline & 1e & - & + & + & + & + & + & 250 \\
\hline Staphilococcus & $1 \mathrm{a}$ & - & - & - & - & + & + & 62.5 \\
\hline
\end{tabular}




\begin{tabular}{lllllllll}
\cline { 3 - 4 } & 1b & - & - & - & + & + & + & 125 \\
ATCC 25923 & 1c & - & - & - & + & + & + & 125 \\
& 1d & - & - & + & + & + & + & 250 \\
& $1 \mathrm{c}$ & - & - & + & + & + & + & 250 \\
\hline
\end{tabular}

\subsection{DPPH radical scavenging activity}

The DPPH assay of 1e gave maximum activity among all the synthesized 1,2,4-triazoles (78.16\%). This was very much close to that of the standard GSH (71.76\%). This enhanced activity of the compound 1e might be attributed due to the presence of -OH group at para position of aromatic nucleus substituted to 1,2,4-triazole. The result is given in the Fig. 1.

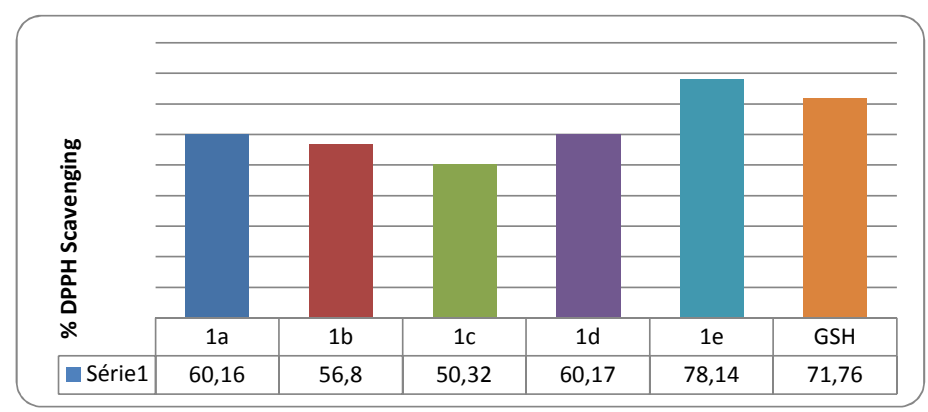

Fig.1. DPPH radical scavenging assay of 1a-1e

\subsection{FRAP assay}

FRAP assay measures the reducing power of the antioxidant molecule i.e. FRAP assay also evaluates the capacity of compound to transfer a hydrogen atom (protection against lipid peroxidation and glutathione oxidation) as well as the capacity of compounds to transfer a single electron. Substances which have reduction potential react with potassium ferricyanide $\left(\mathrm{Fe}^{3+}\right)$ to form potassium ferrocyanide $\left(\mathrm{Fe}^{2+}\right)$ which then reacts with ferric chloride $\left(\mathrm{FeCl}_{3}\right)$ to form ferric ferrous complex that has an absorption maximum at $700 \mathrm{~nm}$.

In FRAP assay, increased absorbance of the compounds indicates increased reducing power. Compounds with higher absorption $(100 \mu \mathrm{g} / \mathrm{mL})$ showed a higher reducing power (Fig.2). These results clearly reveal that compounds have antioxidant activity. Among the synthesized 
compounds, 1d and 1e showed maximum reducing activity which might be due to the presence of electron releasing methyl and hydroxyl group on aromatic nucleus attached to 1,2,4-triazole moiety.

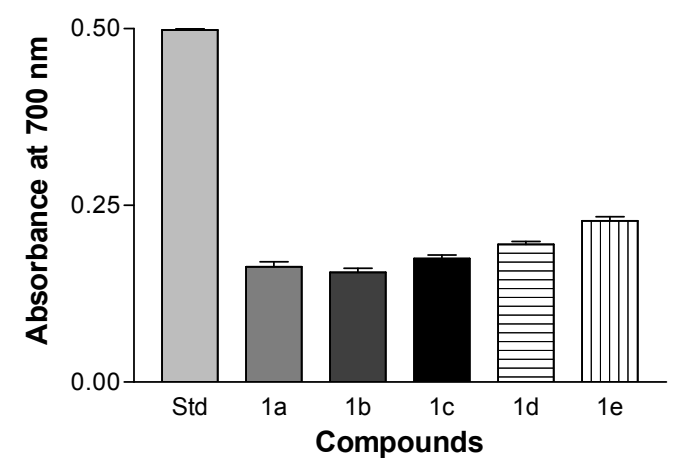

Fig.2. In vitro FRAP assay

\subsection{Lipid Peroxidation Assay}

Lipid peroxidation involves the formation and propagation of lipid radicals with numerous deleterious effects, including destruction of membrane lipids, metabolic disorders and inflammation, and production of malondialdehyde (MDA) is a hallmark of this process [ 8]. Inhibition of lipid peroxidation was assessed by amount of MDA produced. Lipids in egg yolk undergo rapid nonenzymatic peroxidation in the presence of ferrous sulphate. These compounds showed good inhibition of lipid peroxidation. Therefore this suggests that the compounds exhibited significantly to the inhibition of lipid peroxidation. Among the compounds tested, compound 1e exhibited very good activity (Fig.3).This could be attributed due the presence of -OH group on aromatic nucleus substituted to 1,2,4-triazole moiety. These results are also supported by similar studies documented in available literature $[9,10]$. 


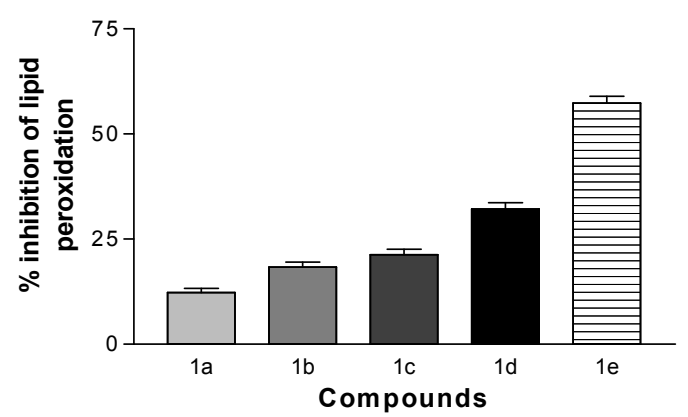

Fig.3. In vitro Lipid Peroxidation Assay

\section{EXPERIMENTAL}

\subsection{Materials and Methods:}

All reagents were purchased from Sigma-Aldrich and used without further purification. Open capillary method was used for determination of melting points; correction factor was not applied to the values reported. Purity of the compound was checked on silica gel precoated TLC plates and visualised using UV chamber. Elemental analysis was carried out by using VARIO EL-III (Elementar Analysensysteme GmBH). The structure of synthesized compounds was characterized by IR, ${ }^{1} \mathrm{H}$ NMR, ${ }^{13} \mathrm{C}$ NMR and LCMS analysis. IR spectra were recorded on Shimadzu 8400S FTIR spectrometer using KBr pellets. ${ }^{1} \mathrm{H}$ NMR spectrum was recorded in DMSO- $\mathrm{d}_{6}$ at $400 \mathrm{MHz}$ and ${ }^{13} \mathrm{C}$ NMR spectrum was recorded in DMSO- $\mathrm{d}_{6}$ at 100MHz. SHIMADZU UV-2550 double beam spectrophotometer with $1 \mathrm{~cm}$ matched quartz cell was used to measure the absorbance.

The 1,2,4-triazoles (1a-1e) were synthesized (Scheme II) from commercially available substituted Phenylaceticacids 1. Thiocarbohydrazide 2 was synthesized by Taguchi method [6]. The synthesis of thiocarbohydrazide (Scheme I) required for the reaction was obtained by condensing hydrazine hydrate and carbon disulphide in the ratio 3:1. It takes 6 hours of heating the reaction mixture at $343 \mathrm{~K}$. Substituted Phenylacetic acid and thiocarbohydrazide were fused under solvent free condition on an oil bath at $413 \mathrm{~K}$ for one hour to get the title 
products. Synthesized compounds were recrystallized from methanol, dried and melting point was determined. Purity of the compounds is determined by HPLC. The structure of all new compounds was established by IR, ${ }^{1} \mathrm{H}-\mathrm{NMR},{ }^{13} \mathrm{C}-\mathrm{NMR}$, LCMS and elemental analysis. The IR spectra of all the synthesized compounds showed absorption bands due to - $\mathrm{NH}$ stretching band in the region $3310-3242 \mathrm{~cm}^{-1}$, $-\mathrm{NH}_{2}$ stretch at 3194-3161 $\mathrm{cm}^{-1},-\mathrm{C}=\mathrm{N}-$ stretch at $1307-1259 \mathrm{~cm}^{-1}$ and the $\mathrm{C}=\mathrm{S}$ stretching band at $772-663 \mathrm{~cm}^{-1}$. These data confirmed formation of triazoles. In $1 \mathrm{H}$ NMR and $13 \mathrm{C}$ NMR spectra, the signals of the protons and carbons of the synthesized compounds were analyzed on the basis of their chemical shifts $(\delta)$.The peak integrating for single proton around the region $\delta 13.5 \mathrm{ppm}$ was assigned to $\mathrm{NH}-\mathrm{SH}$ tautomeric proton. The aromatic proton signals appeared in the region $\delta 6.77-7.46$ ppm, A single peak appeared at $\delta 5.5 \mathrm{ppm}$ was assigned for two protons of $-\mathrm{NH}_{2}$ group attached to triazole ring. These ${ }^{1} \mathrm{H}$ NMR data confirmed the formation of synthesised compounds. In ${ }^{13} \mathrm{C}$ NMR spectra of the newly synthesized compounds, the phenyl ring carbons were resonated in the range of $\delta 120-137 \mathrm{ppm}$. The $-\mathrm{C}=\mathrm{N}$ - peak was observed at $\delta$ 150-159 ppm and the $\mathrm{C}=\mathrm{S}$ peak at $\delta 163-168 \mathrm{ppm}$. The methylene carbon attached to triazole ring resonated around $\delta 27-39 \mathrm{ppm}$. LCMS spectra also showed the respective molecular ionic peaks for the all the triazole derivatives.

The spectral characterization of a representative analogue 4-amino-3-(4-chlorobenzyl)-1H-1,2,4-triazole-5(4H)-thione (1a) is presented as follows. The IR spectrum of 1a showed absorption bands at $3242 \mathrm{~cm}^{-1}$ and $3161 \mathrm{~cm}^{-1}$ were due to $-\mathrm{NH}$ and $-\mathrm{NH}_{2}$ groups respectively. A sharp absorption band at $1294 \mathrm{~cm}^{-1}$ was assigned for the $-\mathrm{C}=\mathrm{N}$ - group of the molecule and an absorption band due $\mathrm{C}=\mathrm{S}$ stretch was seen at $663 \mathrm{~cm}^{-1}$. A band representing $\mathrm{C}-\mathrm{Cl}$ stretch was found at $765 \mathrm{~cm}^{-1}$. The ${ }^{1} \mathrm{H}$ NMR spectrum showed a singlet at $\delta 13.55 \mathrm{ppm}$ integrating for one $\mathrm{NH}-\mathrm{SH}$ tautomeric proton present in the triazole ring. A singlet seen at $\delta 5.55 \mathrm{ppm}$ was assigned to two protons of $-\mathrm{NH}_{2}$ group attached to the triazole ring. Another singlet at $4.04 \mathrm{ppm}$ represented two protons of methylene group connecting triazole and phenyl rings. Multiplet was seen at 7.3-7.39 ppm represented four protons of aromatic ring. In the ${ }^{13} \mathrm{C}$ NMR spectrum, the peak at $\delta 38.90 \mathrm{ppm}$ was assigned for $\mathrm{CH}_{2}$ carbon. Two peaks at $\delta 151 \mathrm{ppm}$ and $\delta 166.10 \mathrm{ppm}$ represent $\mathrm{C}=\mathrm{N}$ and $\mathrm{C}=\mathrm{S}$ carbon 
respectively. The chemical shifts of the aromatic ring carbons were appeared at א128.36-134.42ppm. It was assigned for different aromatic carbons as $\mathrm{C}_{1}-134.42 \mathrm{ppm}, \mathrm{C}_{2}$ \& $\mathrm{C}_{6}-130.75 \mathrm{ppm}, \mathrm{C}_{3} \& \mathrm{C}_{5}-128.36 \mathrm{ppm}, \mathrm{C}_{4}-134.42 \mathrm{ppm}$. LCMS spectrum showed a molecular ion peak at $\mathrm{m} / \mathrm{z} 241.33(\mathrm{M}+1)$ corresponding to the molecular formula $\mathrm{C}_{9} \mathrm{H}_{9} \mathrm{ClN}_{4} \mathrm{~S}$ (Mol. mass 240.7). Elemental analysis supported the further confirmation of the structure of the synthesised compounds. Similarly, structure of all the compounds was determined and the data presented in the experimental section.

\subsection{General Procedure for the synthesis of Thiocarbohydrazide (2)}

Thiocarbohydrazide was prepared by Taguchi method [11]. In a round bottom flask $85 \%$ hydrazine hydrate $(0.3 \mathrm{~mol}, 13.9 \mathrm{ml})$ was placed, which was stirred at $283 \mathrm{~K}$. Carbon disulfide $(0.1 \mathrm{~mol}, 6 \mathrm{ml})$ was added drop wise over about one hour at temperature below $288 \mathrm{~K}$. Later the mixture was agitated for $30 \mathrm{~min}$ at room temperature. Then it was heated at $343 \mathrm{~K}$ for $6 \mathrm{hrs}$. The reaction mixture was cooled to room temperature and precipitate was filtered, washed with ice water and dried.

\subsubsection{General Procedure for the Green Synthesis of (1a-1e)}

The well triturated equimolar mixture of thiocarbohydrazide $\mathbf{2}$ and corresponding substituted phenyl acetic acid $\mathbf{1}$ (Scheme II) was fused in a round bottom flask for one hour on oil bath at $413 \mathrm{~K}$. The reaction mixture was cooled to room temperature and washed with $5 \%$ sodium bicarbonate solution to remove unreacted acid and again washed with water. The compound was dried and recrystallized from methanol [12].

X-ray crystallographic structure of $\mathbf{1} \mathbf{c}$ and $\mathbf{1 e}$ were already reported by the authors and given in Fig.4 and Fig.5 respectively [12,13].

\section{Scheme I:}

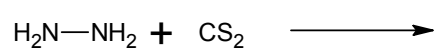<smiles>NNC(=S)NN</smiles> 
Scheme II:
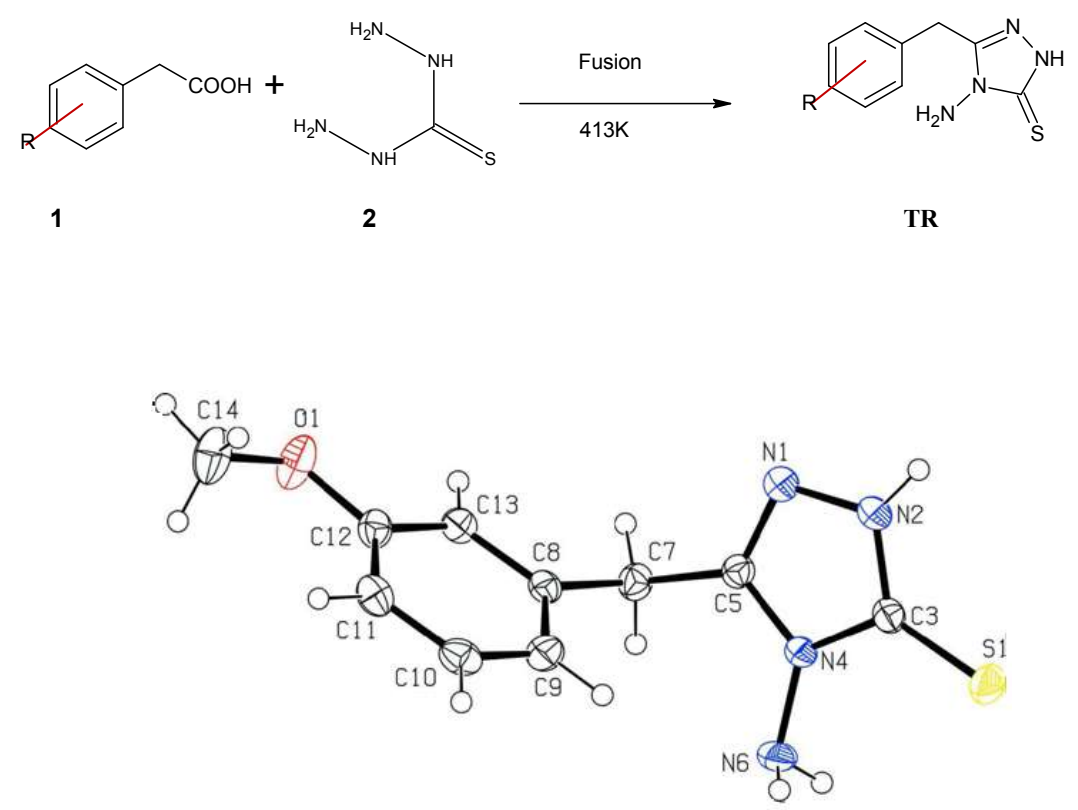

Fig.4. Crystal structure of

4-Amino-3-(3- methoxybenzyl)-1H-1,2,4-triazole-5(4H)-thione (1c) 


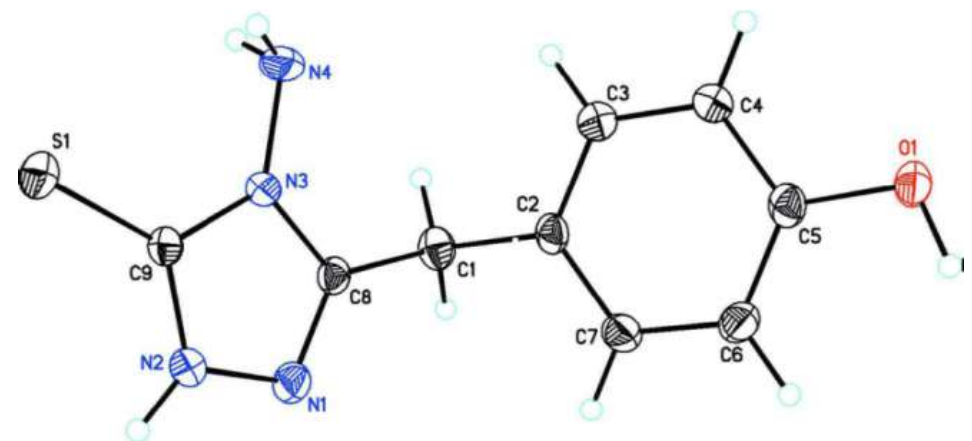

Fig.5. Crystal structure of

4-Amino-3-(4-hydroxybenzyl)-1 $H$-1,2,4-triazole-5(4H)-thione (1e)

\subsubsection{Spectral details}

\section{4-Amino-3-(4-chlorobenzyl)-1H-1,2,4-triazole-5(4H)-thione (1a)}

The compound 1a was obtained as a white solid prepared following the general procedure yield 82\%; m.p.449K; IR(KBr)cm ${ }^{-1}: 3242,3161\left(\mathrm{NH}, \mathrm{NH}_{2}\right), 2934$ (Ar. C-H str.), 1558(NH bend), 1489(C=C ring str.), 1294 (CN str.), 765 (C-Clstr.), 663 (C=S); ${ }^{1} \mathrm{H}$ NMR (400 MHz, DMSO-d $\left.\mathrm{d}_{6}\right)$ : $\delta \mathrm{ppm}, 13.55(1 \mathrm{H}, \mathrm{s}$, of $\mathrm{NH}-\mathrm{SH}), 7.3-7.39(4 \mathrm{H}, \mathrm{m}$, of $\mathrm{Ar}-\mathrm{H}), 5.55\left(2 \mathrm{H}\right.$, s, of $\left.\mathrm{NH}_{2}\right)$, $4.04\left(2 \mathrm{H}\right.$, s, of $\left.\mathrm{CH}_{2}\right) ;{ }^{13} \mathrm{C}$ NMR (100 MHz, DMSO- $\left.\mathrm{d}_{6}\right): \delta \mathrm{ppm}, 38.90\left(\mathrm{CH}_{2}\right), 128.12,128.36$, 130.75, 131.48, 134.42, 134.88 (Aromatic carbons), $151(\mathrm{C}=\mathrm{N}), 166.10(\mathrm{C}=\mathrm{S})$; Anal. cal. for $\mathrm{C}_{9} \mathrm{H}_{9} \mathrm{ClN}_{4} \mathrm{~S}: \mathrm{C}, 44.91 ; \mathrm{H}, 3.77$; N, 23.28. Found: C, 44.87; H, 3.69; N, 23.22.LCMS (ESI-MS) $m / z 241.33(\mathrm{M}+1)$.

\section{4-Amino-3-(2-chlorobenzyl)-1H-1,2,4-triazole-5(4H)-thione (1b)}

The compound $\mathbf{1 b}$ was obtained as a white solid prepared following the general procedure, yield $80 \%$; m.p.465K; IR(KBr)cm ${ }^{-1}: 3280,3171\left(\mathrm{NH}, \mathrm{NH}_{2}\right.$ ), 2930 (Ar. C-H str.), 1597(NH bend), 1494(C=C ring str.), 1307 ( $\mathrm{CN}$ str.), 752 (C-Cl str.), 700(C=S), ${ }^{1} \mathrm{H}$ NMR (400 MHz, DMSO-d $\left.\mathrm{d}_{6}\right)$ : $\delta \mathrm{ppm}, 13.50(1 \mathrm{H}, \mathrm{s}$, of NH-SH$), 7.26-7.46(4 \mathrm{H}, \mathrm{m}$, of $\mathrm{Ar}-\mathrm{H}), 5.58\left(2 \mathrm{H}\right.$, s, of $\left.\mathrm{NH}_{2}\right)$, $4.12\left(2 \mathrm{H}, \mathrm{s}\right.$, of $\left.\mathrm{CH}_{2}\right) ;{ }^{13} \mathrm{C}$ NMR $\left(100 \mathrm{MHz}, \mathrm{DMSO}-\mathrm{d}_{6}\right): \delta \mathrm{ppm}, 38.80\left(\mathrm{CH}_{2}\right), 126.23,127.41$, 
129.57, 130.12, 133.22, 134.33 (Aromatic carbons), $150.11(\mathrm{C}=\mathrm{N}), 163.21(\mathrm{C}=\mathrm{S})$; Anal. cal. for $\mathrm{C}_{9} \mathrm{H}_{9} \mathrm{ClN}_{4} \mathrm{~S}$ : C, 44.91; H, 3.77; N, 23.28. Found: C, 44.77; H, 3.65; N, 23.18.LCMS (ESI-MS) $m / z$ 241.39(M+1).

\section{4-Amino-3-(3- methoxybenzyl)-1H-1,2,4-triazole-5(4H)-thione (1c)}

The compound 1c was obtained as a white solid prepared following the general procedure, yield 83\%; m.p.417K; IR(KBr) $\mathrm{cm}^{-1}: 3310,3194(\mathrm{NH}, \mathrm{NH} 2), 2939$ (Ar. C-H str.), 1583(NH bend), $1481\left(\mathrm{C}=\mathrm{C}\right.$ ring str.), 1259 (CN str.), 772(C=S); ${ }^{1} \mathrm{H}$ NMR (400 MHz, DMSO-d $\left.{ }_{6}\right)$ : Sppm,10.06(1H,s, of NH-SH), 6.77-7.23(4H, m, of Ar-H), $5.54\left(2 \mathrm{H}, \mathrm{s}\right.$, of $\left.\mathrm{NH}_{2}\right), 3.90(2 \mathrm{H}, \mathrm{s}$, of $\left.\mathrm{CH}_{2}\right), 3.72\left(3 \mathrm{H}\right.$, s, of $\left.\mathrm{OCH}_{3}\right) ;{ }^{13} \mathrm{C}$ NMR (100 MHz, DMSO- $\left.\mathrm{d}_{6}\right): \delta \mathrm{ppm}, 30.11\left(\mathrm{CH}_{2}\right), 54.96$ $\left(\mathrm{OCH}_{3}\right), 120.98,121.23,129.16,129.48,136.95,137.13$ (Aromatic carbons), $159.29(\mathrm{C}=\mathrm{N})$, $168.76(\mathrm{C}=\mathrm{S})$; Anal. cal. for $\mathrm{C}_{10} \mathrm{H}_{12} \mathrm{~N}_{4} \mathrm{OS}$ : C,50.83; H, 5.12; N, 23.71. Found: C, 50.77; H, 5.07; N, 23.68.LCMS (ESI-MS) $m / z$ 237.4(M+1).

\section{4-Amino-3-(2-methylbenzyl)-1H-1,2,4-triazole-5(4H)-thione (1d)}

The compound 1d was obtained as a white solid prepared following the general procedure, yield 85\%; m.p.453K; IR(KBr) $\mathrm{cm}^{-1}: 3277,3167(\mathrm{NH}, \mathrm{NH} 2), 2926$ (Ar. C-H str.), 1582(NH bend), $1450\left(\mathrm{C}=\mathrm{C}\right.$ ring str.), 1298 (CN str.), 739(C=S); ${ }^{1} \mathrm{H}$ NMR (400 MHz, DMSO-d $\left.{ }_{6}\right)$ : $\delta$ ppm,13.48(1H,s, of NH-SH), 7.09-7.21(4H, m, of Ar-H), 5.56(2H, s, of $\left.\mathrm{NH}_{2}\right), 3.99(2 \mathrm{H}, \mathrm{s}$, of $\left.\mathrm{CH}_{2}\right), 2.28\left(3 \mathrm{H}\right.$, s, of $\left.\mathrm{CH}_{3}\right) ;{ }^{13} \mathrm{C}$ NMR (100 MHz, DMSO- $\left.\mathrm{d}_{6}\right): \delta \mathrm{ppm}, 19.29\left(\mathrm{CH}_{3}\right), 27.95$ $\left(\mathrm{CH}_{2}\right), 125.59,126.57,129.36,133.69,136.58$ (Aromatic carbons), $150.93(\mathrm{C}=\mathrm{N}), 168.97$ $(\mathrm{C}=\mathrm{S})$; Anal. cal. For $\mathrm{C}_{10} \mathrm{H}_{12} \mathrm{~N}_{4} \mathrm{~S}$ : C, 54.52; H, 5.49; N, 25.43. Found: C, 54.45; H, 5.45; N, 25.39.LCMS (ESI-MS) $m / z$ 221.56(M+1).

\section{4-Amino-3-(4-hydroxybenzyl)-1 $H$-1,2,4-triazole-5(4H)-thione (1e)}

The compound 1e was obtained as a white solid prepared following the general procedure, yield 82\%; m.p.475K; IR(KBr) $\mathrm{cm}^{-1}: 3330$ (OH broad str.)3213, 3024 (NH, NH2), 2754 (Ar. C-H str.), 1589 (NH bend), 1489 (C=C ring str.), 1290 (CN str.), 700(C=S); ${ }^{1}$ NMR (400 MHz, DMSO-d $\left.\mathrm{d}_{6}\right): \delta \mathrm{ppm}, 13.46(1 \mathrm{H}, \mathrm{s}$, of $\mathrm{NH}-\mathrm{SH}), 9.26(1 \mathrm{H}, \mathrm{s}$, of $\mathrm{OH}), 6.66-7.07(4 \mathrm{H}, \mathrm{m}$, of 
Ar-H), 5.50(2H, s, of $\left.\mathrm{NH}_{2}\right), 3.88\left(2 \mathrm{H}, \mathrm{s}\right.$, of $\left.\mathrm{CH}_{2}\right)$; NMR (100 MHz, DMSO- $\left.\mathrm{d}_{6}\right): \delta$ ppm, 39.22 $\left(\mathrm{CH}_{2}\right), 125.26,126.96,129.25,130.73,133.88,133.88$ (Aromatic carbons), $150.32(\mathrm{C}=\mathrm{N})$, 164.55(C=S); Anal. cal. for $\mathrm{C}_{9} \mathrm{H}_{10} \mathrm{~N}_{4} \mathrm{OS}$ : C,48.63; H, 4.53; N, 25.21. Found: C, 48.58; H, 4.48; $\mathrm{N}, 25.15$;

\subsection{Antimicrobial studies}

\subsubsection{Antibacterial activity}

The newly synthesized compounds were screened for their antibacterial activity against Escherichia coli, Bacillus subtilis, Pseudomonas aeruginosa, Staphilococcusaureus bacterial strains by disc diffusion method. The discs measuring $6.25 \mathrm{~mm}$ in diameter were punched from Whatman No. 1 filter paper. Batches of 100 discs were dispensed to each screw capped bottles and sterilized by dry heat at $140{ }^{\circ} \mathrm{C}$ for an hour. The test compounds were prepared with different concentrations using 10\% DMSO. One millilitre containing 100 times the amount of chemical required in each disc was added to each bottle which contains 100 discs. The discs of each concentration were placed in triplicate in nutrient agar medium seeded with fresh bacteria separately. The incubation was carried out at $37.8^{\circ} \mathrm{C}$ for $24 \mathrm{~h}$. Solvent and growth controls were kept [13].

\subsection{In vitroAntioxidant assays:}

\subsubsection{DPPH radical scavenging activity}

DPPH is stable and commercially available organic nitrogen radical and has a UV-visabsorption maximum at $515 \mathrm{~nm}$. Upon reduction, the deep violet colour of the solution fades. The progress of the reaction is monitored by a spectrophotometer at $515 \mathrm{~nm}$.

The ability of 1a -1e to act as hydrogen donor was measured in vitro by stable free radical as 1,1-diphenyl-2-picryl-hydrazyl free radical ( $\left.\mathrm{DPPH}^{\circ}\right)$ as described by Blois [14]. Antioxidant reacts with $\mathrm{DPPH}^{\circ}$, converts it to a colourless, nonradical1,1-diphenyl-2-picrylhydrazine $\left(\mathrm{DPPH}_{2}\right)$. The decolouration from violet indicates the scavenging potential of the antioxidant compound in terms of hydrogen donating ability. The reaction mixture contained $1 \mathrm{ml}$ of $0.3 \mathrm{mM}$ solution of DPPH in methanol and $1 \mathrm{ml}$ of the test compounds or Glutathione (GHS) at $50 \mu \mathrm{g} / \mathrm{ml}$ concentrations. After shaking the mixture, it was allowed to stand for 20 minat room temperature. SHIMADZU UV-2550 
double beam spectrophotometer with $1 \mathrm{~cm}$ matched quartz cell was used to measure the absorbance at $515 \mathrm{~nm}$. The percentage of inhibition was calculated using the equation,

$$
\% \text { Inhibition }=(\text { Control }- \text { Test }) / \text { Control } \times 100
$$

\subsubsection{FRAP assay}

Antioxidant activity was determined by FRAP assay as described by Oyaizu, 1986. According to this method $100 \mu \mathrm{g} / \mathrm{mL}$ of each sample and standard ascorbic acid in DMSO were prepared and mixed $(2.5 \mathrm{~mL})$ with phosphate buffer $(2.5 \mathrm{~mL}, 0.2$ mole, $\mathrm{pH} 6.6)$ and $1.0 \%$ potassium ferricyanide $(2.5 \mathrm{~mL})$. The mixture was incubated at $50{ }^{\circ} \mathrm{C}$ for 20 minutes. Aliquots of $10 \%$ trichloro acetic acid $(2.5 \mathrm{~mL})$ were added to the mixture, centrifuged at $5000 \mathrm{rpm}$ for $10 \mathrm{~min}$. The upper layer of solution $(2.5 \mathrm{~mL})$ was mixed with distilled water $(2.5 \mathrm{~mL})$ and a freshly prepared ferric chloride solution $(0.5 \mathrm{~mL}, 0.1 \%)$ and allowed to stand for 30 minutes in dark to complete the reaction. The control solution was prepared as above, taking water in place of samples. The absorbance was measured at $700 \mathrm{~nm}$ [15].

\subsubsection{Lipid Peroxidation Assay}

A modified Thiobarbituric acid-reactive species (TBARS) assay was used to measure the lipid peroxide formed, using egg yolk homogenates as lipid-rich media. Adapted TBARS method was employed to measure the antioxidant capacity. Briefly, egg homogenate (100 $\mu \mathrm{L}$ of 1:25, $\mathrm{v} / \mathrm{v}$ in phosphate-buffered saline (PBS) of PH 7.4 and $10 \mu \mathrm{L}$ of $100 \mu \mathrm{g} / \mathrm{mL}$ concentration of compound samples were added to a test tube as well as added $25 \mathrm{mmol} / \mathrm{L}$ freshly prepared $\mathrm{FeSO}_{4}$ made up to $300 \mu \mathrm{L}$ with PBS. Homogenate was incubated at $37{ }^{\circ} \mathrm{C}$ for $15 \mathrm{~min}$ and then the reaction was stopped by adding $50 \mu \mathrm{L} 15 \% \mathrm{w} / \mathrm{v}$ Trichloroacetic acid (TCA) and centrifugation (3,500 rpm) for $15 \mathrm{~min}$. An aliquot of $200 \mu \mathrm{L}$ from supernatant was mixed with $100 \mu \mathrm{L}$ thiobarbituricacid (TBA) and heated at $95{ }^{\circ} \mathrm{C}$ for $30 \mathrm{~min}$. After cooling, absorbance of the samples was measured using a spectrophotometer at $532 \mathrm{~nm}[16]$.

$\%$ Inhibition of lipid peroxidation $=100 \times\left(A_{0}-A_{1}\right) / A_{0}$, where $A_{0}$ and $A_{1}$ are the absorbance of control and the compounds or standards respectively.

\section{REFERENCES}

[1] Holla B.S., Rao B.S., Sarojini B.K., Akberali P. M., Kumari N. S., Euro. J. Med. Chem. 
2006, 41, pp. 657-663.

[2] Stefanska J., Szulczyk D., Koziol A.E., Miroslaw B., Kedzierska E., Fidecka S., Busonera B., Sanna G., Giliberti G., La Colla P., et al, Eur. J. Med. Chem. 2012, 55, pp. 205-213.

[3] Gumrukcuoglu N., Serdar M., Celik E., Sevim A., Demirbas N., Turk. J, Chem. 2007, 31, pp. 335- 348.

[4] Reid J.R., Heindel N. O., J. Het. Chem. 1976, 13, pp. 925-928.

[5] Holla B.S., Prasanna C.S., Poojary B., Ashok M., Rao K. S., Shridhara K.,

Z. Naturforsch. 2006, 61, pp. 334-338.

[6] Foroumadi A., Firoozpour L., Emami S., Mansouri S., Ebrahimabadi A.H., Asadipour A., Amini M., Saeid-Adeli N., Shafiee A., Arch. Pharm. Res. 2007, 30, pp. 138-145.

[7] Mokle S.S., Khansole S.V., Patil R.B., Vibhutem Y.B., Int. J. Pharma and Bio Sci. 2010, 1, pp. $1-7$.

[8] Awah F.M., Uzoegwu P.N., Ifeonu P., Oyugi J.O., Rutherford J., Yao X., Fehrmann F., Fowke K.R., Eze M.O, Food Chem. 2012, 131, pp. 1279-1286.

[9] Rajesh M.P., Natvar J.P, J. Adv. Pharm. Edn. \& Res. 2011, 1, pp. 52-68.

[10] Molnar M., Cacic M., Croat. J. Food Sci. Technol. 2012, 4, pp. 54-63.

[11] Zhou J., Wu J., Gao D, J. Chem. Technol.Biotechnol, 2010, 85, pp. 1402-1406

[12] Sarojini B.K., Manjula P.S., Hegde G., Kour D., Anthal S., Gupta V.K., Rajni Kant, ActaCryst. 2013, 69, pp. 728.

[13] Sarojini B.K., Vidyagayatri M., Darshanraj C.G., Bharath B.R., Manjunatha H, Lett. in Drug Discov. \& desgn, 2010, 7, pp. 214-224.

[14] Blois M.S., Nature, 1958, 181, pp. 1199-1200

[15] Oyaizu M., Jap. J. Nutri. 1986, 44, pp. 307-315.

[16] Banerjee A., Dasgupta N., De B., Food Chem. 2005, 90, pp. 727-733.

How to cite this article:

P. S. Manjula, B. K. Sarojini, C. G. Darshan Raj. Antibacterial and in vitro antioxidant activities of some 4-Amino-1,2,4-Triazole-5(4H)-Thione derivatives. J. Fundam. Appl. Sci., 2015, 7(3), 394-407. 